\title{
Is remission of depressive symptoms in primary care a realistic goal? A meta-analysis \\ Marliese Y Dawson ${ }^{1}$, Erin E Michalak ${ }^{1}$, Paul Waraich ${ }^{2}$, J Ellen Anderson ${ }^{3}$ and Raymond W Lam*1
}

\begin{abstract}
Address: ${ }^{1}$ Division of Clinical Neuroscience, Department of Psychiatry, University of British Columbia, 2255 Wesbrook Mall, Vancouver, BC, Canada V6T 2A1, ${ }^{2}$ Division of Mental Health Services, Department of Psychiatry, Universityof British Columbia, 2250 Wesbrook Mall, Vancouver, BC, Canada V6T 1W6 and '3Family Physician, 6625B Sooke Road, Sooke, BC, Canada V0S 1N0

Email: Marliese Y Dawson - mdawson@interchange.ubc.ca; Erin E Michalak - emichala@interchange.ubc.ca; Paul Waraich - waraich@interchange.ubc.ca; J Ellen Anderson - jeanderson@telus.net; Raymond W Lam* - r.lam@ubc.ca

* Corresponding author
\end{abstract}

Published: 07 September 2004

BMC Family Practice 2004, 5:19 doi:10.1 186/147|-2296-5-19
Received: 07 April 2004

Accepted: 07 September 2004

This article is available from: http://www.biomedcentral.com/I47I-2296/5/19

(C) 2004 Dawson et al; licensee BioMed Central Ltd.

This is an open-access article distributed under the terms of the Creative Commons Attribution License (http://creativecommons.org/licenses/by/2.0), which permits unrestricted use, distribution, and reproduction in any medium, provided the original work is properly cited.

\begin{abstract}
Background: A primary goal of acute treatment for depression is clinical remission of symptoms. Most meta-analyses of remission rates involve randomized controlled trials (RCTs) using patients from psychiatric settings, but most depressed patients are treated in primary care. The goal of this study was to determine remission rates obtained in RCTs of treatment interventions for Major Depressive Disorder (MDD) conducted in primary care settings.

Methods: Potentially relevant studies were identified using computerized and manual search strategies up to May 2003. Criteria for inclusion included published RCTs with a clear definition of remission using established outcome measures.

Results: A total of 13 studies ( $N=3202$ patients) meeting inclusion criteria were identified. Overall remission rates for active interventions ranged between $50 \%$ and $67 \%$, compared to $32 \%$ for pill placebo conditions and 35\% for usual care conditions.

Conclusions: Remission rates in primary care studies of depression are at least as high as for those in psychiatric settings. It is a realistic goal for family physicians to target remission of symptoms as an optimal outcome for treatment of depression.
\end{abstract}

\section{Background}

Major depressive disorder (MDD) is one of the most common and disabling of medical conditions [1]. The Canadian Community Health Survey recently reported a oneyear prevalence rate of $4.5 \%$ for $\mathrm{MDD}$, indicating that over 1.1 million Canadians suffer significant distress and impairment in function due to depression [2]. The economic costs of depression are estimated at over $\$ 5$ billion annually [3]. Depression is currently the fourth-ranked medical condition contributing to global burden of disease, and is estimated to rise to second overall by the year $2010[4]$.

There are many effective treatments for MDD, including psychotherapy and antidepressants. Traditionally, efficacy in randomized controlled trials (RCTs) for depression has been determined on the basis of score changes in rating scales such as the Hamilton Depression Rating Scale 
(HDRS) [5] or the Montgomery-Asberg Depression Rating Scale (MADRS) [6]. Clinical outcome has been usually assessed by clinical response rates, typically defined as a $50 \%$ or greater reduction from baseline scores on these rating scales [7]. Although obtaining clinical response represents an important therapeutic milestone, it does not necessarily indicate a complete recovery from MDD, since many patients with clinical response will still be left with substantial residual symptoms of depression. Studies have shown that the presence of residual symptoms after an episode of MDD is associated with higher risk of relapse, recurrence, chronicity, suicide, development of cardiovascular disease, and poor quality of life [8-10].

Such findings suggest that the goals of acute treatment (approximately the first 8-12 weeks or so of treatment) for MDD should be clinical remission, a clinical state distinguished by minimal residual symptoms, rather than just response [11-13]. Clinical remission is typically defined as a score within the normal range on a given outcome measure (e.g., 17-item HDRS score of 7 or less; MADRS score of 12 or less; Clinical Global Impression [CGI] [14] severity score of "Normal, not at all ill"), although there is still some uncertainty as to the validity of these cutoff scores for symptom remission [15]. The achievement of remission is of considerable clinical importance as it predicts decreased risk of relapse and greater psychosocial functioning than typically observed in patients who have achieved clinical response alone [1618]. Clinical remission is now identified and promoted as a clinical target for successful management of MDD in many clinical practice guidelines [13,19-21].

Increasing numbers of treatment studies are now explicitly reporting both clinical response and remission rates in assessment of outcome. A meta-analysis of 8 antidepressant studies of venlafaxine versus selective serotonin reuptake inhibitors [SSRIs] and placebo reported mean remission rates of $45 \%, 35 \%$, and $25 \%$, respectively [22]. A subsequent meta-analysis of 32 RCTs comparing venlafaxine, SSRIs and other antidepressants reported a mean overall remission rate of $42 \%$ [23]. Finally, a meta-analysis of 6 RCTs comparing antidepressants and psychotherapy in patients with MDD reported mean remission rates of $46 \%$ for each treatment [24].

All the studies in these systematic reviews involved patients in psychiatric or mixed settings. However, most people suffering from MDD will be managed in the primary care setting [25]. Approximately $5 \%$ to $10 \%$ of all patients consulting a general practitioner have MDD, with prevalence estimates being two to three times higher when other depressive disorders (i.e., minor depression or dysthymia) are included [26]. It remains unclear whether the remission rates reported in psychiatric settings can be extrapolated to primary care environments, although it is of clinical importance for primary care physicians to know whether obtaining remission is a realistic goal for their patients. There has been a recent surge in studies assessing a variety of treatment interventions for depression in primary care settings, making this an opportune time to perform a meta-analysis to address this question. Hence, the primary objective of this study was to determine remission rates obtained in RCTs of treatment interventions for MDD conducted in primary care settings.

\section{Methods}

Potentially relevant studies were identified using computerized and manual search strategies. The computerized search conducted in June, 2003 included the databases: Medline, Psych Info, Embase, Biosis, Cochrane Database of Systematic Reviews, and Cochrane Controlled Trials Register and Current Controlled Trials (1981-May 2003). The search terms used were 'depressive disorder' or 'depression' combined with 'primary care' and 'remission' and/or variants. The bibliographies of relevant articles were also manually searched. Two reviewers (MYD and RWL) collected and independently assessed abstracts for inclusion criteria. Disagreements were resolved with consensus.

\section{Inclusion criteria}

Studies were included if they were RCTs with original data comparing one or more interventions (e.g., antidepressant vs. cognitive behavioral therapy) and published in English. Only studies of predominantly adult populations, as opposed to exclusively child or elderly patient populations, were included. Although the focus was principally upon patients with MDD (studies primarily dealing with minor depression and dysthymia were excluded), the criteria for a diagnosis of MDD was intentionally broad in order to capture the heterogeneity of the sample and allow the results to be as generalizable as possible. Included studies also had to use a standardized outcome measure (e.g., HDRS, MADRS, Beck Depression Inventory [BDI] [27]) and provide explicit criteria for remission. While the definition of remission varied among the studies (Table 1), for the purpose of this meta-analysis we accepted each study's definition of remission, which usually was a score within the normal range on the outcome measure.

\section{Data extraction}

Two independent reviewers (MYD and EEM) extracted data from studies using a checklist developed for this study, with disagreements resolved by a third reviewer (RWL). A conservative measure of remission rate was calculated from each study using an intent-to-treat analysis [28], even if this method was not used in the study. For example, some studies calculated remission rates using 
Table I: Summary of included studies in meta-analysis of remission rates.

\begin{tabular}{|c|c|c|c|c|c|c|c|}
\hline Study & $\begin{array}{c}\text { Diagnostic } \\
\text { Criteria }\end{array}$ & $\begin{array}{l}\text { Follow up } \\
\text { Period }\end{array}$ & $\begin{array}{c}\text { Remission } \\
\text { Criteria }\end{array}$ & Total $\mathbf{N}$ & Intervention & $\begin{array}{c}\text { Intervention } \\
\text { Remission } \\
\text { Rate }\end{array}$ & Remission \% \\
\hline \multicolumn{8}{|c|}{ Psychological Intervention Only } \\
\hline $\begin{array}{l}\text { Dowrick et al., } 2000 \\
\text { [3I] }\end{array}$ & $\begin{array}{l}\text { DSM-IV criteria for } \\
\text { MDD or Adjustment } \\
\text { Disorder }\end{array}$ & 6 months & $\begin{array}{l}\text { No MDD } \\
\text { detected by } \\
\text { SCAN } \\
\text { interview }\end{array}$ & 425 & $\begin{array}{l}\text { - PST } \\
\text { - Usual Care } \\
\text {-Prevention } \\
\text { course }\end{array}$ & $\begin{array}{l}\cdot 58 / 128 \\
\cdot 76 / 189 \\
\cdot 44 / 108\end{array}$ & $\begin{array}{l}\cdot 45 \\
\cdot 38 \\
\cdot 41\end{array}$ \\
\hline \multicolumn{8}{|c|}{ Antidepressant Intervention Only } \\
\hline $\begin{array}{l}\text { Benkert et al., } 2000 \\
\text { [32] }\end{array}$ & $\begin{array}{l}\text { DSM-IV criteria for } \\
M D D \text { and HDRS } \geq 18\end{array}$ & 6 weeks & HDRS $\leq 7$ & 275 & $\begin{array}{l}\text { - Mirtazapine } \\
\text { - Paroxetine }\end{array}$ & $\begin{array}{l}\cdot 52 / 139 \\
\cdot 42 / 136\end{array}$ & $\begin{array}{l}\cdot 37 \\
\cdot 31\end{array}$ \\
\hline Patris et al., 1996 [33] & $\begin{array}{l}\text { DSM-IIIR criteria for } \\
\text { MDD }\end{array}$ & 8 weeks & MADRS $\leq 12$ & 357 & $\begin{array}{l}\text { - Citalopram } \\
\text { - Fluoxetine }\end{array}$ & $\begin{array}{l}\cdot 114 / 173 \\
\cdot 110 / 184\end{array}$ & $\begin{array}{l}\cdot 66 \\
.60\end{array}$ \\
\hline $\begin{array}{l}\text { Wade et al., } 2002 \\
\text { [34] }\end{array}$ & $\begin{array}{l}\text { DSM-IV criteria for } \\
\text { MDD }\end{array}$ & 8 weeks & MADRS $\leq 12$ & 380 & $\begin{array}{l}\text { - Escitalopram } \\
\text { - Placebo }\end{array}$ & $\begin{array}{l}\cdot 92 / 191 \\
\cdot 64 / 189\end{array}$ & $\begin{array}{l}\cdot 48 \\
\cdot 34\end{array}$ \\
\hline \multicolumn{8}{|c|}{ Psychological Intervention + Antidepressants } \\
\hline $\begin{array}{l}\text { Chilvers et al., } 2001 \\
\text { [35] }\end{array}$ & $\begin{array}{l}\text { Diagnosed as MDD } \\
\text { by GP }\end{array}$ & 12 months & $\begin{array}{l}\text { RDC }<4, \mathrm{BDI} \\
<10 \text {, or clear } \\
\text { documentation } \\
\text { in GP notes that } \\
\text { patient is well }\end{array}$ & 103 & $\begin{array}{l}\text { Randomised } \\
\text { only: } \\
\text { - } \\
\text { Antidepressant } \\
\text { - Counselling }\end{array}$ & $\begin{array}{l}\cdot 39 / 51 \\
\cdot 33 / 52\end{array}$ & $\begin{array}{l}\cdot 76 \\
\cdot 63\end{array}$ \\
\hline $\begin{array}{l}\text { Mynors-Wallis et al., } \\
\text { 1995 [36] }\end{array}$ & $\begin{array}{l}\text { Diagnosed as MDD } \\
\text { by GP }\end{array}$ & 12 weeks & $\begin{array}{l}\mathrm{HDRS} \leq 7 \text { or } \\
\mathrm{BDI} \leq 8\end{array}$ & 91 & $\begin{array}{l}\text { - PST } \\
\text { - Amitriptyline } \\
\text { - Placebo }\end{array}$ & 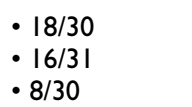 & $\begin{array}{l}\cdot 60 \\
\cdot 52 \\
\cdot 27\end{array}$ \\
\hline $\begin{array}{l}\text { Mynors-Wallis et al., } \\
2000 \text { [37] }\end{array}$ & $\begin{array}{l}\text { RDC criteria for } \\
\text { MDD }\end{array}$ & 12 months & HDRS $\leq 8$ & 151 & $\begin{array}{l}\text { - PST-group } \\
\text { •PST-RN } \\
\cdot \\
\text { Antidepressant } \\
\dot{\text { PST+antidepres }} \\
\text { sant }\end{array}$ & $\begin{array}{l}\cdot 24 / 39 \\
\cdot 23 / 41 \\
\cdot 20 / 36 \\
\cdot 23 / 35\end{array}$ & $\begin{array}{l}\cdot 62 \\
\cdot 56 \\
\cdot 56 \\
\cdot 56\end{array}$ \\
\hline $\begin{array}{l}\text { Schulberg et al., } 1998 \\
\text { [38] }\end{array}$ & $\begin{array}{l}\text { DSM-IIIR criteria for } \\
\text { MDD }\end{array}$ & 8 months & HDRS $\leq 7$ & 184 & $\begin{array}{l}\text { - IPT } \\
\text { - Nortriptyline }\end{array}$ & $\begin{array}{l}\cdot 49 / 93 \\
\cdot 52 / 91\end{array}$ & $\begin{array}{l}\cdot 57 \\
\cdot 53\end{array}$ \\
\hline Scott et al., 1992 [39] & $\begin{array}{l}\text { DSM-IIIR criteria for } \\
\text { MDD }\end{array}$ & 4 months & HDRS $\leq 7$ & 121 & $\begin{array}{l}\text { - CBT } \\
\text { - Counselling } \\
\text { - Amitriptyline } \\
\text { - Usual care }\end{array}$ & $\begin{array}{r}\cdot 12 / 30 \\
\cdot 22 / 30 \\
\cdot 18 / 31 \\
\cdot 14 / 30\end{array}$ & $\begin{array}{l}\cdot 40 \\
\cdot 73 \\
\cdot 58 \\
\cdot 47\end{array}$ \\
\hline \multicolumn{8}{|c|}{ Program Interventions } \\
\hline Katon et al., 1999 [40] & $\begin{array}{l}\text { Diagnosed as MDD } \\
\text { by GP }\end{array}$ & 6 months & $\begin{array}{l}\text { Presence of } 0 \\
\text { or I SCID- } \\
\text { assessed } \\
\text { symptoms }\end{array}$ & 228 & $\begin{array}{l}\text { - Collaborative } \\
\text { care } \\
\text { - Usual Care }\end{array}$ & $\begin{array}{l}\cdot 50 / 114 \\
\cdot 35 / 114\end{array}$ & $\begin{array}{l}\cdot 44 \\
\cdot 31\end{array}$ \\
\hline $\begin{array}{l}\text { Katzelnick et al., } 2000 \\
{[4 I]}\end{array}$ & $\begin{array}{l}\text { Diagnosed as MDD } \\
\text { by GP and HDRS } \geq \\
15\end{array}$ & 12 months & HDRS $\leq 7$ & 407 & $\begin{array}{l}\text { - Depression } \\
\text { management } \\
\text { - Usual care }\end{array}$ & $\begin{array}{l}\cdot 92 / 218 \\
\cdot 49 / 189\end{array}$ & $\begin{array}{l}\cdot 42 \\
\cdot 26\end{array}$ \\
\hline $\begin{array}{l}\text { Kutcher et al., } 2002 \\
\text { [42] }\end{array}$ & $\begin{array}{l}\text { Diagnosed as MDD } \\
\text { by GP }\end{array}$ & 29 weeks & $\begin{array}{l}8 \text { weeks or } \\
\text { longer with } \\
\text { HDRS } \leq 10\end{array}$ & 269 & $\begin{array}{l}\text { - Sertraline } \\
\text { - Sertraline + } \\
\text { adherence } \\
\text { program }\end{array}$ & $\begin{array}{l}\cdot 84 / 138 \\
\cdot 88 /|3|\end{array}$ & $\begin{array}{l}.61 \\
.67\end{array}$ \\
\hline Rost et al., 2002 [43] & $\begin{array}{l}\text { Diagnosed as MDD } \\
\text { by GP }\end{array}$ & 24 months & CES-D $\leq 16$ & 211 & $\begin{array}{l}\text { - Enhanced } \\
\text { depression care } \\
\text { - Usual care }\end{array}$ & $\begin{array}{l}\cdot 85 / 115 \\
\cdot 39 / 96\end{array}$ & $\begin{array}{l}\cdot 74 \\
\cdot 41\end{array}$ \\
\hline
\end{tabular}

(Abbreviations: BDI - Beck Depression Inventory, CBT - Cognitive Behavioural Therapy, CES-D - Centre for Epidemiological Studies - Depression Scale, HDRS - Hamilton Depression Rating Scale, HSCL-D-20 - 20-item Hopkins Symptom Check List, IPT-Interpersonal Psychotherapy, MADRS Montgomery-Asberg Depression Rating Scale, MDD - Major Depressive Disorder, PST - Problem Solving Therapy, PST-PC - Problem Solving Therapy, administered by Primary Care Physician, PST-RN - Problem Solving Therapy, administered by Registered Nurse, RDC - Research Diagnostic Criteria, SCAN - Schedules of Clinical Assessment in Neuropsychiatry, SCID - Structured Clinical Interview for DSM-III-R.) 
only patients who returned for one follow-up visit postrandomization, or who had completed a course of treatment. The denominator used for remission rate was the total number of patients randomized to treatment, whether or not they were counted in the ensuing analysis. The numerator was the number of patients in remission reported in the study, regardless of the denominator used in the study analysis.

The type of intervention was classified as placebo, "usual care" by clinician (standard treatment by a patient's own physician), psychotherapy treatment only, antidepressant treatment only, psychotherapy plus antidepressant treatment, or program intervention (e.g., collaborative care using other health professionals; educational programs targeted at quality improvement for prescribing practices).

\section{Statistics}

Each set of rates was pooled based on a Bayesian approach to meta-analysis using the Fastpro software program (version 1.7) by Eddy and Hasselblad. Readers interested in a more detailed discussion of this approach should refer to Eddy et al [29]. The pooled means and confidence intervals were calculated using Jeffrey's prior and a random effects model.

\section{Results}

The initial electronic and bibliographic search found 63 articles of which 47 warranted more detailed review based on the published abstract. Of these, 34 articles were excluded due to methodology (not RCTs, 4 studies), lack of remission criteria (18 studies), diagnostic criteria (not MDD, 11 studies) and age criteria (geriatric, 4 studies) (some studies were excluded for multiple reasons, see Additional File 1). A final count of 13 studies met the full inclusion criteria (Table 1). In total, 3202 primary care outpatients ( $75 \%$ female, $25 \%$ male) were included in the analysis. The mean age of the participants was 32.1 years (range 18-73 years). The average length of follow-up was 32 weeks (range 6-104 weeks).

The study interventions and methodologies were too heterogeneous to allow for a meaningful statistical comparison of results between treatments. Figure 1 shows mean remission rates for specific interventions. Overall remission rates for active interventions, regardless of type, ranged between $50 \%$ and $67 \%$, compared to $32 \%$ for pill placebo conditions and $35 \%$ for usual care conditions. There were a sufficient number of antidepressant arms in the studies to permit the summary of remission rates by duration of follow-up period. For antidepressant studies with follow-up of 6 months or less, mean remission rate was 51.4\% (95\% C.I., 43.1\%-59.6\%); for antidepressant studies with greater than 6 months of follow-up, mean remission rate was $62.3 \%$ (95\% C.I., $48.9 \%-74.8 \%$ ).

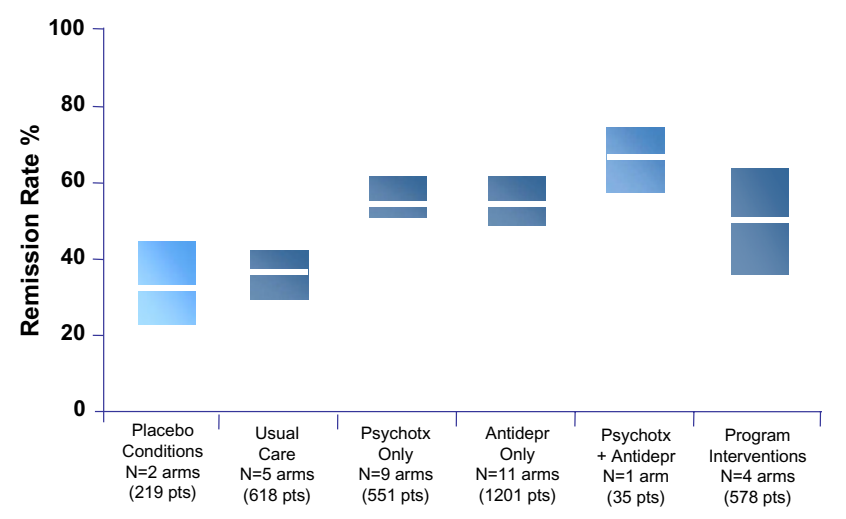

Figure I

Remission rates for specific treatment conditions from randomized controlled trials (RCTs) of interventions for depression in primary care settings. The white lines represent the mean remission rates and the boxes represent the $95 \%$ confidence interval. $\mathrm{N}$ is the number of treatment arms in the RCTs (Note: Psychotx = Psychotherapy, Antidepr = Antidepressants, $\mathrm{pts}=$ patients $)$.

\section{Discussion}

This review of research assessing remission of depressive symptoms in primary care populations identified 13 studies meeting the inclusion criteria. Overall remission rates (regardless of type of intervention but excluding placebo or usual care arms) ranged between $50 \%$ and $67 \%$. These rates are equivalent to, or indeed greater than, those reported in meta-analyses of studies examining pharmacological or psychological interventions for depression in psychiatric populations, in which the overall remission rates ranged between $35 \%$ and $46 \%$ [22-24]. On the one hand, we might have predicted this finding as studies conducted in primary care settings tend to include more patients with mild to moderate depression (although we excluded studies that focused exclusively upon minor depression or dysthymia), whereas patients referred to psychiatric settings are more likely to have moderate to severe depression. Primary care treatment trials also tend to be longer, favouring a higher remission rate; whereas the mean follow-up period of studies included in the current analysis was 9 months, it was only 7 weeks and 10 weeks in the two previous meta-analyses of pharmacological interventions for MDD [22,23], and 16 weeks in the meta-analysis of antidepressant versus psychotherapeutic interventions [24]. Conversely, we might have predicted that we would observe lower remission rates in the current meta-analysis as it included a number of studies with 
more lenient exclusion criteria than typically used in psychiatric clinical trials. In particular, the program intervention studies tend to include more heterogeneous patient populations as they do not routinely exclude patients with psychiatric or medical comorbidities, factors that may lessen the likelihood of obtaining remission of depressive symptoms [30].

While it was not within the scope of the current study to compare the effectiveness of different treatment interventions in improving remission rates, we can report on the trends we observed in the data. Antidepressant and psychotherapy interventions delivered in isolation showed similar remission rates (54\% for both). Combination antidepressant plus psychotherapy interventions showed somewhat higher rates $(67 \%)$, although this category included only 1 arm with only 35 patients. Program interventions had a mean remission rate of $50 \%$, and all treatment interventions fared better than either placebo (32\%) or usual care (35\%).

The studies identified in our review were quite heterogeneous in nature, ranging from those that looked solely at the effects of a particular pharmacological agent, through to complex program initiatives that incorporated a variety of interventions at different levels of care. This heterogeneity limits our ability to make broad comments about remission rates in primary care, but was not unexpected, as we wanted to capture the diversity of treatment interventions for depression currently being tested in this setting. Other potential limitations of the study include that fact that we only assessed published studies written in English and that we used a conservative measure of remission rate. Finally, we also used the definition of remission as specified by each individual study. While these definitions were similar to those widely used in RCTs conducted in psychiatric settings, and thus are useful for comparison, there is current controversy about depression scales and which cutoff scores indicate true remission of symptoms [15].

\section{Conclusions}

This meta-analysis serves to answer an important clinical question about the feasibility of obtaining remission of symptoms of MDD in primary care patients. Our results indicate that this is a realistic goal in this population, although further research is still required to determine whether certain treatment modalities (or combinations of treatment interventions) are superior to others in achieving higher remission rates. Future research should also focus upon developing pragmatic strategies for general practitioners to implement evidence-based guidelines concerning the treatment of depression to clinical remission.

\section{Authors' contributions}

MYD and EEM conducted the data extraction, wrote the initial draft of the manuscript, interpreted results, and revised the manuscript. PW provided statistical consultation and analysis, and revised the manuscript. JEA interpreted the results and revised the manuscript. RWL conceived the initial idea, developed the method, interpreted results, revised the manuscript, and provided financial resources for the study. All authors read and approved the final manuscript.

\section{Competing interests}

RWL is on advisory/speaker boards or has received research funds from: AstraZeneca, Biovail, Canadian Network for Mood and Anxiety Treatments, Eli Lilly, GlaxoSmithKline, Janssen-Ortho, Litebook, Inc., Lundbeck, Merck, Organon, Roche, Shire, Servier, and Wyeth.

\section{Additional material}

\section{Additional File 1}

Studies excluded from the review

Click here for file

[http://www.biomedcentral.com/content/supplementary/14712296-5-19-S1.pdf]

\section{Acknowledgments}

Dr. Michalak was supported by a Canadian Institutes of Health Research/ Wyeth Canada Postdoctoral Fellowship Award.

\section{References}

I. Parikh SV, Lam RW: Clinical guidelines for the treatment of depressive disorders, I. Definitions, prevalence, and health burden. Can J Psychiatry 200I, 46 Suppl I: I3S-20S.

2. Statistics Canada : Canadian Community Health Survey: Mental health and well-being. www statcan ca/Daily/English/030903/ d030903a htm, accessed November 9, 2003.

3. Desjardins B, Laurier C: The burden of depression in Canada. Value in Health 2002, 5:229.

4. Murray CJ, Lopez AD: Alternative projections of mortality and disability by cause 1990-2020: Global Burden of Disease Study. Lancet 1997, 349: |498-1504.

5. Hamilton $M$ : Development of a rating scale for primary depressive illness. Br J Soc Clin Psych 1967, 6:278-296.

6. Montgomery SA, Asberg M: A new depression scale designed to be sensitive to change. Br J Psychiatry 1979, I 34:382-389.

7. Frank E, Prien RF, Jarrett RB, Keller MB, Kupfer DJ, Lavori PW, Rush AJ, Weissman MM: Conceptualization and rationale for consensus definitions of terms in major depressive disorder. Remission, recovery, relapse, and recurrence. Arch Gen Psychiatry I99I, 48:85I-855.

8. Judd LL, Akiskal HS, Maser JD, Zeller PJ, Endicott J, Coryell W, Paulus MP, Kunovac JL, Leon AC, Mueller TI, Rice JA, Keller MB: Major depressive disorder: a prospective study of residual subthreshold depressive symptoms as predictor of rapid relapse. J Affect Disord 1998, 50:97-108.

9. Judd LL, Paulus MJ, Schettler PJ, Akiskal HS, Endicott J, Leon AC, Maser JD, Mueller T, Solomon DA, Keller MB: Does incomplete recovery from first lifetime major depressive episode herald a chronic course of illness? Am J Psychiatry 2000, I 57:I50 I-I504.

10. Judd LL, Akiskal HS, Maser JD, Zeller PJ, Endicott J, Coryell W, Paulus MP, Kunovac JL, Leon AC, Mueller TI, Rice JA, Keller MB: A pro- 
spective |2-year study of subsyndromal and syndromal depressive symptoms in unipolar major depressive disorders. Arch Gen Psychiatry 1998, 55:694-700.

II. Rush AJ, Trivedi MH: Treating depression to remission. Psychiatric Annals 1995, 25:704-705

12. Thase ME: The clinical, psychosocial, and pharmacoeconomic ramifications of remission. Am J Manag Care 200I, 7:S377-S385.

13. Reesal RT, Lam RW: Clinical guidelines for the treatment of depressive disorders. II. Principles of management. Can J Psychiatry 200I, 46 Suppl I:2IS-28S.

14. Guy W: ECDEU Assessment Manual for Psychopharmacology: Publication ADM 76-338. Edited by: GuyW. Rockville, MD, US Department of Health, Education and Welfare; 1976:217-222.

15. Zimmerman M, Posternak MA, Chelminski I: Implications of using different cut-offs on symptom severity scales to define remission from depression. Int Clin Psychopharmacol 2004, 19:215-220.

16. Thase ME, Simons AD, McGeary J, Cahalane JF, Hughes C, Harden T, Friedman E: Relapse after cognitive behavior therapy of depression: potential implications for longer courses of treatment. Am J Psychiatry 1992, I 49: 1046- 1052.

17. Fava GA, Fabbri S, Sonino N: Residual symptoms in depression: an emerging therapeutic target. Prog Neuropsychopharmacol Biol Psychiatry 2002, 26:1019-1027.

18. Miller IW, Keitner GI, Schatzberg AF, Klein DN, Thase ME, Rush AJ, Markowitz JC, Schlager DS, Kornstein SG, Davis SM, Harrison WM, Keller MB: The treatment of chronic depression, part 3: psychosocial functioning before and after treatment with sertraline or imipramine. J Clin Psychiatry 1998, 59:608-619.

19. American Psychiatric Association : Practice guideline for the treatment of patients with major depressive disorder (revision). Am J Psychiatry 2000, 157:1-45

20. Bauer M, Whybrow PC, Angst J, Versiani M, Moller H-J, Disorders WFSBP Task Force on Treatment Guidelines for Unipolar Depressive: World Federation of Societies of Biological Psychiatry (WFSBP) guidelines for biological treatment of unipolar depressive disorders, part I: Acute and continuation treatment of major depressive disorder. World Journal of Biological Psychiatry 2002, 3:5-43.

21. Depression Guideline Panel: Treatment of Major Depression. Clinical Practice Guideline. Washington, Agency for Health Care Policy and Research; 1993.

22. Thase ME, Entsuah AR, Rudolph RL: Remission rates during treatment with venlafaxine or selective serotonin reuptake inhibitors. Br J Psychiatry 200I, I78:234-24I.

23. Smith D, Dempster C, Glanville J, Freemantle N, Anderson I: Efficacy and tolerability of venlafaxine compared with selective serotonin reuptake inhibitors and other antidepressants: a metaanalysis. Br J Psychiatry 2002, 180:396-404.

24. Casacalenda N, Perry JC, Looper K: Remission in major depressive disorder: a comparison of pharmacotherapy, psychotherapy, and control conditions. Am J Psychiatry 2002, 159: I 354-1360.

25. Barrett JE, Barrett JA, Oxman TE, Gerber PD: The prevalence of psychiatric disorders in a primary care practice. Archives of General Psychiatry 1988, 45:1100-1106.

26. Katon $\mathrm{W}$, Schulberg $\mathrm{H}$ : Epidemiology of depression in primary care. Gen Hosp Psychiatry 1992, 1 4:237-247.

27. Beck AT, Ward CH, Mendelson M, Mock J, Erbaugh J: An inventory for measuring depression. Arch Gen Psychiatry 1961, 4:561-57I.

28. Collaboration Cochrane: Cochrane Manual Oxford, Cochrane Collaboration; 2004

29. Eddy DM, Hasselbald V, Shachter R: Meta-analysis by the confidence interval method. The statistical synthesis of evidence. San Diego, Academic Press Inc.; 1992.

30. Cuffel BJ, Azocar F, Tomlin M, Greenfield SF, Busch AB, Croghan TW: Remission, residual symptoms, and nonresponse in the usual treatment of major depression in managed clinical practice. J Clin Psychiatry 2003, 64:397-402.

31. Dowrick C, Dunn G, Ayuso-Mateos JL, Dalgard OS, Page H, Lehtinen V, Casey P, Wilkinson C, Vazquez-Barquero JL, Wilkinson G: Problem solving treatment and group psychoeducation for depression: multicentre randomised controlled trial. Outcomes of Depression International Network (ODIN) Group. British Medical Journal - Clinical Research 2000, 32 I: |450-| 454
32. Benkert O, Szegedi A, Kohnen R: Mirtazapine compared with paroxetine in major depression. J Clin Psychiatry 2000, 61:656-663.

33. Patris M, Bouchard JM, Bougerol T, Charbonnier JF, Chevalier JF, Clerc G, Cyran C, Van Amerongen P, Lemming O, Hopfner Petersen HE: Citalopram versus fluoxetine: a double-blind, controlled, multicentre, phase III trial in patients with unipolar major depression treated in general practice. Int Clin Psychopharmacol 1996, II:I29-136.

34. Wade A, Lemming O.Michael, Hedegaard K.Bang: Escitalopram 10 $\mathrm{mg} /$ day is effective and well tolerated in a placebo-controlled study in depression in primary care. International Clinical Psychopharmacology 2002, 17:95-102.

35. Chilvers C, Dewey M, Fielding K, Gretton V, Miller P, Palmer B, Weller D, Churchill R, Williams I, Bedi N, Duggan C, Lee A, Harrison G: Antidepressant drugs and generic counselling for treatment of major depression in primary care: randomised trial with patient preference arms. BM] 200I, 322:772-775.

36. Mynors-Wallis LM, Gath DH, Lloyd-Thomas AR, Tomlinson D: Randomised controlled trial comparing problem solving treatment with amitriptyline and placebo for major depression in primary care. BMJ 1995, 31 0:44I-445.

37. Mynors-Wallis LM, Gath DH, Day A, Baker F: Randomised controlled trial of problem solving treatment, antidepressant medication, and combined treatment for major depression in primary care. $B M J 2000,320: 26-30$

38. Schulberg HC, Pilkonis PA, Houck P: The severity of major depression and choice of treatment in primary care practice. J Consult Clin Psychol 1998, 66:932-938.

39. Scott Al, Freeman CP: Edinburgh primary care depression study: treatment outcome, patient satisfaction, and cost after 16 weeks. $B M]$ 1992, 304:883-887.

40. Katon W, Von Korff M., Lin E, Simon G, Walker E, Unutzer J, Bush T, Russo J, Ludman E: Stepped collaborative care for primary care patients with persistent symptoms of depression: a randomized trial. Arch Gen Psychiatry 1999, 56: I 109-III 5.

4I. Katzelnick DJ, Simon GE, Pearson SD, Manning WG, Helstad CP, Henk HJ, Cole SM, Lin EH, Taylor LH, Kobak KA: Randomized trial of a depression management program in high utilizers of medical care. Arch Fam Med 2000, 9:345-35I.

42. Kutcher S, Leblanc J, Maclaren C, Hadrava V: A randomized trial of a specific adherence enhancement program in sertralinetreated adults with major depressive disorder in a primary care setting. Prog Neuropsychopharmacol Biol Psychiatry 2002, 26:591-596.

43. Rost K, Nutting P, Smith JL, Elliott CE, Dickinson M: Managing depression as a chronic disease: a randomised trial of ongoing treatment in primary care. BMJ 2002, 325:934.

\section{Pre-publication history}

The pre-publication history for this paper can be accessed here:

http://www.biomedcentral.com/1471-2296/5/19/prepub

Publish with Bio Med Central and every scientist can read your work free of charge

"BioMed Central will be the most significant development for disseminating the results of biomedical research in our lifetime. "

Sir Paul Nurse, Cancer Research UK

Your research papers will be:

- available free of charge to the entire biomedical community

- peer reviewed and published immediately upon acceptance

- cited in PubMed and archived on PubMed Central

- yours - you keep the copyright
BioMedcentral 